\title{
Biochar and fulvic acid to activate soil fertility for achieving agro-ecology benefits in a newly reclaimed coastal wetland of China
}

\author{
Yunpeng Sun ${ }^{1,2}$, Jinsong Yang ${ }^{1 *}$, Rongjiang Yao ${ }^{1}$, Xiaobing Chen ${ }^{3}$ \\ ${ }^{1}$ State Key Laboratory of Soil and Sustainable Agriculture, Institute of Soil Science, Chinese Academy of Sciences, Nanjing 210008, China, \\ ${ }^{2}$ University of Chinese Academy, Beijing, China, ${ }^{3}$ Coastal Zone Environmental Process Key Laboratory/Yantai Coastal Zone Research \\ Institute, Chinese Academy of Sciences, Yantai 264003, China
}

\section{A B S T R A C T}

Reclamation of coastal tidal flat lands for obtaining more lands has lasting for many years in China. More attention should be paid on soil and water pollution for protecting coastal ecosystem during the period of saline soil amelioration. A field experiment was conducted for two years in eastern China to investigate the effects of different rates of biochar (BC) (at 0, 7.5, and $30 \mathrm{t} \mathrm{ha}^{-1}$ ) and/or fulvic acid (FA) (at $0,0.075 \mathrm{t} \mathrm{ha}^{-1}$ ) with/without nitrogen (N) fertilizer on the soil physical, chemical, and nutritional properties, as well as crop yield, with a maize-barley rotation. Results showed that $\mathrm{N}$ application caused soil compaction, and $\mathrm{BC}+\mathrm{FA}$ treatments decreased soil bulk density (ranging from 1.22 to $1.28 \mathrm{~g} \mathrm{~cm}^{3}$ ) and improved water retention under the condition. Extreme precipitation accelerated soil de-salinization during the crop cultivation (soil EC decreased to the low value ranging from 127 to $141 \mu \mathrm{S} \mathrm{cm}^{-1}$, after maize harveseted). $\mathrm{N}$ addition improved grain yield of maize (increased by $105 \%$ under BC $30+F A+N$, compared with the CK treatment), but there was no significant difference between the $\mathrm{N}$ and no- $\mathrm{N}$ added treatments. However, the grain yield and straw weight of barley in with- $\mathrm{N}$ treatments were twice as much as those of the no- $\mathrm{N}$ treatments. The soil nutrion contents (total nitrogen and phosphorus content) after maize and barley crops were higher, under no- $\mathrm{N}$ treatments compared to the with- $\mathrm{N}$ treatments. A lower $\mathrm{pH}(8,78)$ and higher $\mathrm{Ca}^{2+}+\mathrm{Mg}^{2+}$ content $(0.24$ $\sim 0.26 \mathrm{~g} \mathrm{~kg}^{-1}$ ) existed in $\mathrm{BC}_{30}+\mathrm{FA}$ treated plots after maize and barley crops. Replacement of nitrogen fertilizer by $\mathrm{BC}$ and $\mathrm{FA}$ in the coastal saline soil was feasible in a short time. Therefore, nitrogen fertilizer usage should be regulated for protecting the coastal ecology system, and also achieving agricultural benefits.

Keywords: Coastal wetland; Sodium; Nitrogen; Barley; Precipitation

\section{INTRODUCTION}

Coastal wetland are ecosystems with complex interactions between marine and terrestrial processes. It is one of the most biologically diverse ecological landscapes in nature. China has a vast coastal area throughout its coastline. The coastal wetlands play an important role in protection of critical habitat, degradation of pollutants, maintenance of regional of ecological balance, and promotion of the economic growth (He et al., 2014; Yu et al., 2019).

Tidelands are part of the coastal wetlands, while tidelands reclamation is capable of creating abundant land to alleviate the pressure from land shortages in many countries (Kim et al., 2016). Mainland China has been experiencing a massive transfer of tidal flats into the land to satisfy the land-use needs of the developing society. Coastal tidal land reclamation has caused significant changes to the coastal environment since the founding of the People's Republic of China (Sun et al., 2011). In Jiangsu Province, Eastern China, a total land area of approximately 0.26 million hectares was reclaimed between the years 1951 to 2007. According to the land-use plan of Jiangsu Province, over 180,000 ha of tidal flats will be reclaimed from 2010 to 2020 (Nan et al., 2016).

Reclaimed tidelands have generally been used for agriculture; supplementing shortages in farmland triggered by increased urbanization and industrialization. However, the reclaimed tidelands were currently not suitable for

\footnotetext{
${ }^{*}$ Corresponding author:

Jinsong Yang, State Key Laboratory of Soil and Sustainable Agriculture, Institute of Soil Science, Chinese Academy of Sciences, Nanjing 210008, China. Tel.: +86-025-86881222. E-mail: jsyang@issas.ac.cn
}

Received: 24 April 2019; Revised: 02 June 2019 
cultivation because soils were high in both soluble sodium and exchangeable sodium, which cause soil dispersion and swelling that lead to poor structure (Yu et al., 2010). In addition to structural losses, salt restriction through osmotic stress and toxic functions of specific ions threatens crop growth (Deinlein et al., 2014). Furthermore, excessive salts could cause phytotoxicity, water deficiency and nutrient imbalance (Rawat et al., 2011). These changes are all harmful to long-term plant growth performance (Sousa et al., 2017).

The environmental impact of reclamation has drawn much attention. It has been suggested that the global increase of marine harmful algal blooms is primarily due to eutrophication, caused by nitrogen and phosphorus enrichment (Liu et al., 2013a,b). Moreover, a report showed prominent nitrogen pollution in the intertidal sediments of Jiangsu Province, and about $70 \%$ of inorganic nitrogen comes from losses of agricultural nitrogen fertilizer (Wang, 2017). It has been reported that phosphorus is the primary factor limiting agricultural production in the reclaimed coastal land in Eastern China (Yin et al., 2017). Therefore, how to maintain and remediate a sustainable utilization of these reclaimed tidal land soils has become an urgent task. However, some existing technologies (e.g., water leaching, organic matter, gypsum, microorganism fertilizer) for ameliorating the coastal soils have been limited for their high costs, low efficiency, ecological hazard, or secondary pollution (Chen et al., 2017; Min et al., 2016; Visconti et al., 2010; Yin et al., 2017). Hence, a modified method with multiple benefits of environment-friendly, productivity, and cost-effectiveness is urgently required for mitigating soil salinity, preventing nutrient leaching, and improving soil properties in the reclaimed tidal flat soil.

Biochar, a biomass that is produced at temperature ranging from 300 to $1000^{\circ} \mathrm{C}$, and under a limited supply of oxygen, has recently become an interesting subject of study (Lehmann et al., 2011). Biochar is produced with the intent to be applied to soil as a means of improving soil productivity, carbon (C) storage, or filtration of percolating soil water (Lehmann, 2007). The application of biochar will significantly improve the soil nutrients and soil organism communities (Lehmann et al., 2011). The utilization of biochar in improving the coastal saline soil had been gradually attracted more attention. For example, Sun et al (2017) reported that biochar application to the coastal saline soils with appropriate rates could reduce $\mathrm{N}$ leaching, keep soil $\mathrm{N}$ retention, and not increase $\mathrm{NH}_{3}$ volatilization, which was beneficial for sustainable use of saline soils. In addition, in the saline-sodic soil, application of biochar increased plant height and nutritional contents, and confirmed the potential to assist in restoring vegetation of low salinesodic soils (Drake et al., 2016). Some researchers showed the ability of biochar to immobilize and absorb various environmental pollutants including pesticides and heavy metals indicating that biochar is useful for toxicity reduction (Abbas et al., 2017; Almaroai et al., 2014). However, not all the biochars with complex properties are suitable for the coastal soil reclamation because of the difference of the biomass and the productive process (Luo et al., 2017). So the modified right biochar has been highly proposed for the right soil (Abiven et al., 2014). Fulvic acid (FA), a derivative of the humic acid, was adopted in the present study to improve the amelioration efficiency of biochar on reclaimed tidal flat land. FA possesses high ion exchange and hydrolysis capacity, and it modifies the soil structure by binding to clay, silt, and sand due to its colloidal characteristics. Otherwise, FA can function as a plant hormone, protects plants against abiotic stress conditions, and increases soil fertility (Fang et al., 2016; Li et al., 2013; Yang et al., 2014). However, it is less stable in soil due to its greater exposure to microbial degradation (Dinler et al., 2016). Therefore, it is reasonable to hypothesize that combined application of fulvic acid and biochar is more efficient than their individual application for ameliorating saline soil.

In this study, a field experiment was conducted to investigate the effects of combined and individual application of biochar, fulvic acid, and nitrogen fertilizer (urea) on soil properties and crop growth under maize-barley rotation. The experiment was perfomed in a reclaimed tidal flat land in Jiangsu Province. Soil salt stress and nutrient content inhibited crop production. However, in order to avoid the $\mathrm{N}$ pollution mitigation, it is very necessary to optimize nitrogen application during the crop cultivation. The primary aim of the present study was to determine the effects of biochar and/or fulvic acid replace $\mathrm{N}$ on soil quality improvement, salt alleviation, and crop yields.

\section{MATERIALS AND METHODS}

\section{Experimental site}

The field experiment site was located in Tiaozini Reclamation Area (3250'6.88"N, 12056'35.56"E), Jianggang Township, Dongtai City, Jiangsu province, China. The study field was reclaimed in October 2013, which is located on the shore of China Yellow Sea. Land leveling was finished in November 2015, covering an area of 1.5 hectares. The climate is subtropical and characterized by monsoon and oceanity with large seasonal fluctuations in precipitation and temperature (Fig. 1). The long-term average annual precipitation and evaporation was $1042 \mathrm{~mm}$ and $1417 \mathrm{~mm}$ respectively. The mean annual temperature was $14.6^{\circ} \mathrm{C}$. The total sunshine time per year amounted to $2130.5 \mathrm{~h}$, and annual frost-free days per year reached $220 \mathrm{~d}$. The soil was derived from marine and fluvial sediments, 
silty loam in texture. The soil was moderately alkaline, high in organic carbon and normal in salt. The contents of heavy metals in the soil surface accorded with the national standard for the soil and environment quality generally (Table 1). The cultivation of summer maize, winter barley or wheat was a local conventional cropping system.

\section{Biochar and fulvic acid used}

Biochar (BC) used for the field experiment was made with pyrolysis of wheat straw at $350-550^{\circ} \mathrm{C}$ in a vertical kiln from the Shangqiu Sanli New Energy Company, China. Before the application of biochar to the soil, biochar was ground to pass a $2 \mathrm{~mm}$ sieve, thoroughly homogenized, and then sprayed it with fresh water at the weight ratio of 4:1. Fulvic acid (FA) was produced by airslake coal from Pingxiang Red land Humic Acid Co. Ltd. Properties of BC and FA are listed in Table 1.

\section{Experimental design}

Field experiments were conducted to study the effects of $\mathrm{BC}$ and/or FA replace of nitrogen fertilizer on crop

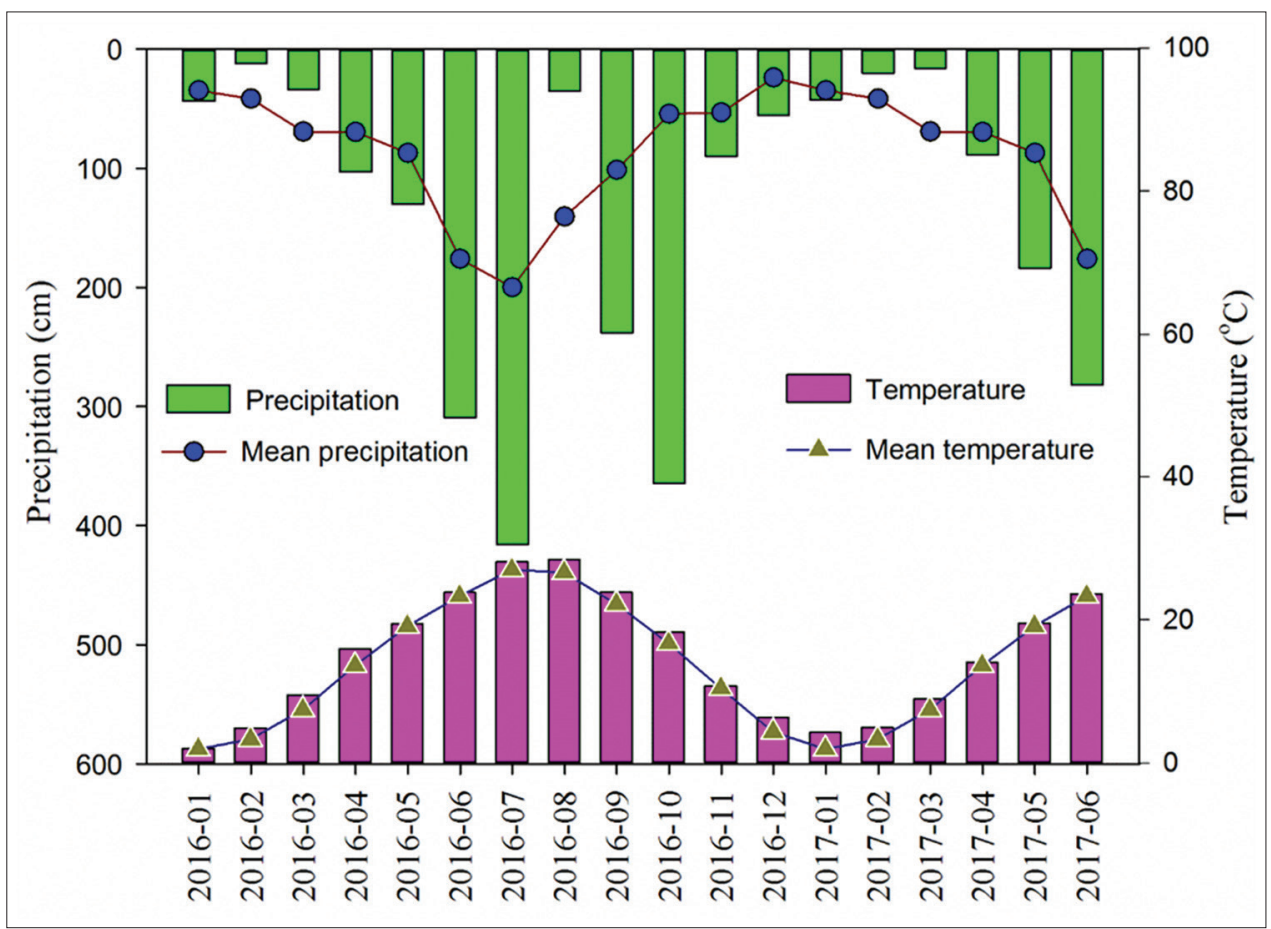

Fig 1 . Monthly precipitation $(\mathrm{cm})$ and monthly average daily temperature $\left({ }^{\circ} \mathrm{C}\right)$ during the test.

Table 1: Physical and chemical properties of soil, biochar and fulvic acid

\begin{tabular}{|c|c|c|c|c|c|}
\hline Soil & & Biochar & & Fulvic acid & \\
\hline $\mathrm{EC}\left(\mu \mathrm{S} \mathrm{cm^{-1 } )}\right.$ & 480.00 & Biomass & wheat straw & Pure substance (\%) & 99.80 \\
\hline $\mathrm{pH}$ & 9.04 & Pyrolysis temperature $\left({ }^{\circ} \mathrm{C}\right)$ & $350-550$ & $\mathrm{pH}$ & 4.52 \\
\hline TOC $\left(\mathrm{g} \mathrm{kg}^{-1}\right)$ & 7.69 & $\mathrm{EC}\left(\mathrm{dS} \mathrm{m}^{-1}\right)$ & 0.82 & $\mathrm{C}(\%)$ & 55.90 \\
\hline Bulk density $\left(\mathrm{g} \mathrm{cm}^{-3}\right)$ & 1.34 & $\mathrm{pH}$ & 10.4 & $\mathrm{H}(\%)$ & 2.35 \\
\hline Total N $\left(\mathrm{g} \mathrm{kg}^{-1}\right)$ & 1.06 & TOC $\left(\mathrm{g} \mathrm{kg}^{-1}\right)$ & 467 & $\mathrm{~N}(\%)$ & 0.76 \\
\hline Available $\mathrm{P}\left(\mathrm{mg} \mathrm{kg}^{-1}\right)$ & 26.80 & Bulk density $\left(\mathrm{g} \mathrm{cm}^{-3}\right)$ & 0.65 & $\mathrm{~S}(\%)$ & 2.18 \\
\hline Total K $\left(\mathrm{g} \mathrm{kg}^{-1}\right)$ & 0.21 & $N(\%)$ & 5.90 & $\mathrm{O}(\%)$ & 38.81 \\
\hline $\mathrm{Cr}\left(\mathrm{mg} \mathrm{kg}^{-1}\right)$ & 58.30 & Total ash (\%) & 20.8 & $\mathrm{H} / \mathrm{C}(\%)$ & 0.50 \\
\hline $\mathrm{Zn}\left(\mathrm{mg} \mathrm{kg}^{-1}\right)$ & 50.73 & $\mathrm{H}(\%)$ & 6.69 & $\mathrm{O} / \mathrm{C}(\%)$ & 0.52 \\
\hline $\mathrm{Ni}\left(\mathrm{mg} \mathrm{kg}^{-1}\right)$ & 22.65 & $\mathrm{O}(\%)$ & 35.9 & $\mathrm{~N} / \mathrm{C}(\%)$ & 0.01 \\
\hline $\mathrm{Cu}\left(\mathrm{mg} \mathrm{kg}^{-1}\right)$ & 14.33 & $\mathrm{Ca}\left(\mathrm{mg} \mathrm{kg}^{-1}\right)$ & 10.10 & Acidic groups $\left(\mathrm{mmol} \mathrm{g}^{-1}\right)$ & 9.39 \\
\hline $\mathrm{Pb}\left(\mathrm{mg} \mathrm{kg}^{-1}\right)$ & 13.91 & $\mathrm{Mg}\left(\mathrm{mg} \mathrm{kg}^{-1}\right)$ & 6.09 & & \\
\hline As $\left(\mathrm{mg} \mathrm{kg}^{-1}\right)$ & 7.52 & $\mathrm{Fe}\left(\mathrm{mg} \mathrm{kg}^{-1}\right)$ & 4.27 & & \\
\hline $\mathrm{Cd}\left(\mathrm{mg} \mathrm{kg}^{-1}\right)$ & 0.094 & $\mathrm{~K}\left(\mathrm{mg} \mathrm{kg}^{-1}\right)$ & 265.70 & & \\
\hline $\mathrm{Hg}\left(\mathrm{mg} \mathrm{kg}^{-1}\right)$ & 0.013 & CEC $\left(\mathrm{cmol} \mathrm{kg}^{-1}\right)$ & 35.15 & & \\
\hline Sand (\%) & 3.48 & & & & \\
\hline Silt (\%) & 75.76 & & & & \\
\hline Clay (\%) & 20.76 & & & & \\
\hline
\end{tabular}

${ }^{a} \mathrm{EC}$, electrical conductivity; $\mathrm{pH}$, soil reaction; TOC, total organic carbon; $\mathrm{N}$, nitrogen; $\mathrm{P}$, phosphorus; $\mathrm{K}$, potassium 
growth and soil salinity alleviation. $\mathrm{BC}$ was added into the soil at the content of $0,7.5$ and $30 \mathrm{t} \mathrm{ha}^{-1}$. FA was added at the content of $0,0.075 \mathrm{tha}^{-1}$. Urea ( $\mathrm{N}$ fertilizer) as the nitrogen fertilizer with different dose was used for maize and barley cultivation. Twelve treatments were studied in a randomized block design with three replications. P fertilizer was applied in all treatments with the same dose during the crop cultivation. The treatment neither added $\mathrm{BC}$ nor FA referred to as control check (CK). The block size was $6 \mathrm{~m} \times 8 \mathrm{~m}$, and with $35 \mathrm{~cm}$ away from each other. Maize (Suyv 80) was cultivated from June 2016 to October 2016, and barley (Supi 4) was planted from November 2016 to April 2017. FA was dissolved in water and then sprayed on soil or biochar surface before maize sowing. The BC or FA was broadcasted on the soil surface and thoroughly mixed with the topsoil by machinery plowing to a depth of $20 \mathrm{~cm}$. And the plots treated in barley cultivation were amended no more biochar but with only FA in the same dose before barley sowing. Chemical fertilizer was applied following the local conventional fertilization. For maize, basal fertilizers of urea and calcium superphosphate were applied at $135 \mathrm{~kg} \mathrm{~N} \mathrm{ha}{ }^{-1}$ and $90.0 \mathrm{~kg} \mathrm{P}_{2} \mathrm{O}_{5}$ ha $^{-1}$ respectively. At the jointing stage, $90 \mathrm{~kg} \mathrm{~N} \mathrm{ha}^{-1}$ as urea was additionally ditch-applied in the row as supplementary fertilizer to a depth of $15 \mathrm{~cm}$ and covered by the soil-using hoe. For barley, $30 \mathrm{~kg} \mathrm{ha}^{-1}$ of $\mathrm{N}, 49.5 \mathrm{~kg} \mathrm{ha} \mathrm{g}^{-1} \mathrm{P}$ were supplied for the basal fertilizer; also, $15 \mathrm{~kg} \mathrm{ha}{ }^{-1}$ of $\mathrm{N}$ were supplied in the green stage and heading stage.

\section{Sampling and analysis}

Prior to the initiation of the experiment, the soil in the 0-20 cm was obtained on 20 May 2016 to measure the basal properties. After maize harvest, soil samples at depth of 0-20 cm from 5 locations across each experimental field in an $S$-shaped pattern were collected using an Eijkelkamp core sampler on 30 September 2016. Soil samples were dried in the air-dry room, and then removed the visible foreign substances for the following processing. Air-dried samples were ground to pass through a $2-\mathrm{mm}$ sieve for determining soil salinity (measured as electrical conductivity (EC)), $\mathrm{pH}$ and soluble ion composition $\left(\mathrm{Na}^{+}, \mathrm{K}^{+}, \mathrm{Ca}^{2+}\right.$, $\mathrm{Mg}^{2+}, \mathrm{Cl}^{-}, \mathrm{CO}_{3}^{2-}, \mathrm{HCO}_{3}$, and $\mathrm{SO}_{4}^{2-}$ ) in $1: 5 \mathrm{w} / \mathrm{v}$ ratio soil suspensions. Soils were saved for nutrient (N, P, and $\mathrm{K})$ analysis according to the standard protocol (Bao, 2000). Maize plant heights were measured in each experimental plot during the ripping stage. Maize grains were tiled on plastic film in clear weather, then determined the grain weight and thousand kernel weight of the dried grains. The barley was harvested on 20 April 2017 and weighed after dried at $70^{\circ} \mathrm{C}$. After the plants collected, soil samples $(0-20 \mathrm{~cm})$ were obtained by handle augers. The total organic carbon (TOC) was measured to investigate the effects of treatments on soil quality. Undisturbed soil cores were taken from soil at depth of $10-15 \mathrm{~cm}$ using a cylinder of $100 \mathrm{~cm}^{3}$ in volume to measure bulk density (BD), soil porosity and water retention capability.

For all soil samples, soil EC and $\mathrm{pH}$ were measured in deionized water at a ratio of $1: 5 \mathrm{w} / \mathrm{v}$ by a conductivity and $\mathrm{pH}$ sensors (SevenExcellence Cond meter, Mettler Toledo, $\mathrm{CH})$. $\mathrm{N}$ and $\mathrm{P}$ were determined by an auto discrete analyzer (CleverChem, Germany). TOC content was measured using an oxidation method with potassium dichromate. $\mathrm{Na}^{+}$ and $\mathrm{K}^{+}$were measured using flame photometry (FP6400, JingKe, China). $\mathrm{Ca}^{2+}, \mathrm{Mg}^{2+}, \mathrm{Cl}^{-}, \mathrm{CO}_{3}^{2-}, \mathrm{HCO}_{3}^{-}$, and $\mathrm{SO}_{4}^{2-}$ were determined by potentiometric titration (T70, Teller Toledo, $\mathrm{CH})$. Samples are weighted by electronic scales (MS, Mettler Toledo, $\mathrm{CH}$ ) or electronic platform scales (BBA231, Mettler Toledo, CH) for satisfying different weighing precision demands.

\section{Statistical analysis}

All results were expressed as means and standard deviations (SD). This paper adopted SigmPlot 12.5 for graphing. A one-way analysis of variance (ANOVA) was used to test the significant differences among the treatments, and the statistically significant differences of means were analyzed by a least significant difference (LSD) test $(P<0.05)$ using SPSS 19.0 software for Windows (SPSS Inc., Chicago, IL, USA).

\section{RESULTS}

\section{Soil salinity and ion composition}

There was a slight increase in soil $\mathrm{pH}$ among all treatments after maize cultivaiton. However, compared with the initial value, electrical conductivity (EC) decreased significantly. The $\mathrm{EC}$ values of $\mathrm{BC}+\mathrm{FA}+\mathrm{N}$ treatments were low, and there was significant differences between $\mathrm{BC}+\mathrm{FA}$ and $\mathrm{CK}$ treatments (Table 2). The effect on soil EC remained nosignificant after the barley crop, but the soil $\mathrm{pH}$ decreased significantly compared with the initial value (Table 3 ). The soil $\mathrm{pH}$ of treatments which contain $\mathrm{N}$ was higher than that in non- $\mathrm{N}$ treatments after maize, but lower after barley. The lowest $\mathrm{Na}^{+}$content and the highest $\mathrm{K}^{+}$content attained in $\mathrm{BC}_{30}+\mathrm{FA}$ followed by $\mathrm{BC}_{30}+\mathrm{FA}+\mathrm{N}$ after maize and barley crops (Table 2,3). The $\mathrm{Ca}^{2+}+\mathrm{Mg}^{2+}$ content increased with different biochar levels and $\mathrm{FA}$ or $\mathrm{N}$ addition further increased its values. Whereas, there was no significant difference in $\mathrm{Ca}^{2+}+\mathrm{Mg}^{2+}$ content between $\mathrm{N}$ and non- $\mathrm{N}$ treatments which contain same biochar dose. A higher $\mathrm{Ca}^{2+}+\mathrm{Mg}^{2+}$ content was observed with the more biochar addition. The similar trend was observed for $\mathrm{Cl}^{-}$after maize and barley crops. No significant difference was found in $\mathrm{HCO}_{3}{ }^{-}+\mathrm{CO}_{3}{ }^{2-}$ and $\mathrm{SO}_{4}{ }^{2-}$ values after barley, and their total content was about $0.1 \mathrm{~g} \mathrm{~kg}^{-1}$. 
Sun, et al.

Table 2: Influence of biochar, fulvic acid and nitrogen fertilizer on soil salinity $(0-20 \mathrm{~cm}$, after maize)

\begin{tabular}{|c|c|c|c|c|c|c|c|}
\hline Treatment & $\begin{array}{c}E C \\
\left(\mu \mathrm{sm}^{-1}\right)\end{array}$ & $\mathrm{pH}$ & $\begin{array}{c}\mathrm{K}^{+} \\
\left(\mathrm{g} \mathrm{kg}^{-1}\right) \\
\end{array}$ & $\begin{array}{c}\mathrm{Na}^{+} \\
\left(\mathrm{g} \mathrm{kg}^{-1}\right)\end{array}$ & $\begin{array}{c}\mathrm{Ca}^{2+}+\mathrm{Mg}^{2+} \\
\left(\mathrm{g} \mathrm{kg}^{-1}\right)\end{array}$ & $\begin{array}{c}\mathrm{Cl}^{-} \\
\left(\mathrm{g} \mathrm{kg}^{-1}\right)\end{array}$ & $\begin{array}{c}\text { SAR } \\
\left(\mathrm{mmol}_{\mathrm{e}} \mathrm{l}^{-1}\right)^{0.5}\end{array}$ \\
\hline $\mathrm{CK}$ & $176.33 \pm 19.60^{\mathrm{ab}}$ & $9.13 \pm 0.07$ & $0.08 \pm 0.01^{\mathrm{e}}$ & $0.24 \pm 0.02^{\mathrm{a}}$ & $0.18 \pm 0.04^{b}$ & $0.46 \pm 0.05^{a b}$ & $0.82 \pm 0.12^{\mathrm{a}}$ \\
\hline $\mathrm{N}$ & $189.62 \pm 10.24^{\mathrm{a}}$ & $9.08 \pm 0.14$ & $0.10 \pm 0.01^{c d}$ & $0.22 \pm 0.01^{\mathrm{a}}$ & $0.17 \pm 0.13^{b}$ & $0.51 \pm 0.04^{\mathrm{a}}$ & $0.78 \pm 0.09^{a}$ \\
\hline $\mathrm{BC}_{7.5}+\mathrm{N}$ & $170.33 \pm 8.74^{\mathrm{ab}}$ & $9.30 \pm 0.14$ & $0.13 \pm 0.02^{\mathrm{bcd}}$ & $0.23 \pm 0.03^{\mathrm{a}}$ & $0.19 \pm 0.06^{a b}$ & $0.18 \pm 0.07^{c}$ & $0.76 \pm 0.06^{\mathrm{ab}}$ \\
\hline $\mathrm{BC}_{30}+\mathrm{N}$ & $154.08 \pm 7.81^{b}$ & $9.16 \pm 0.06$ & $0.16 \pm 0.04^{b}$ & $0.16 \pm 0.04^{b}$ & $0.20 \pm 0.00^{\mathrm{ab}}$ & $0.43 \pm 0.01^{\mathrm{ab}}$ & $0.51 \pm 0.12^{\mathrm{c}}$ \\
\hline $\mathrm{FA}+\mathrm{N}$ & $148.25 \pm 8.54^{b}$ & $9.17 \pm 0.07$ & $0.15 \pm 0.01^{b}$ & $0.19 \pm 0.03^{a}$ & $0.25 \pm 0.05^{\mathrm{ab}}$ & $0.35 \pm 0.01^{c}$ & $0.53 \pm 0.06^{c}$ \\
\hline $\mathrm{BC}_{7.5}+\mathrm{FA}+\mathrm{N}$ & $135.57 \pm 14.53^{c}$ & $9.20 \pm 0.10$ & $0.14 \pm 0.02^{\mathrm{bc}}$ & $0.18 \pm 0.02^{\mathrm{ab}}$ & $0.23 \pm 0.03^{\mathrm{ab}}$ & $0.29 \pm 0.07^{c}$ & $0.53 \pm 0.08^{c}$ \\
\hline $\mathrm{BC}_{30}+\mathrm{FA}+\mathrm{N}$ & $135.33 \pm 7.51^{c}$ & $9.00 \pm 0.04$ & $0.17 \pm 0.04^{b}$ & $0.12 \pm 0.04^{c}$ & $0.28 \pm 0.03^{a}$ & $0.27 \pm 0.09^{b}$ & $0.31 \pm 0.09^{d}$ \\
\hline $\mathrm{BC}_{7.5}$ & $159.33 \pm 13.61^{b}$ & $9.22 \pm 0.09$ & $0.10 \pm 0.03^{d}$ & $0.21 \pm 0.02^{a}$ & $0.23 \pm 0.08^{\mathrm{ab}}$ & $0.35 \pm 0.05^{b}$ & $0.63 \pm 0.11^{b}$ \\
\hline $\mathrm{BC}_{30}$ & $145.49 \pm 23.52^{b}$ & $9.17 \pm 0.05$ & $0.11 \pm 0.01^{c}$ & $0.21 \pm 0.04^{\mathrm{a}}$ & $0.21 \pm 0.07^{a b}$ & $0.68 \pm 0.03^{a}$ & $0.66 \pm 0.23^{b c}$ \\
\hline $\mathrm{FA}$ & $166.00 \pm 32.19^{b}$ & $9.14 \pm 0.17$ & $0.09 \pm 0.02^{d}$ & $0.17 \pm 0.05^{\mathrm{ab}}$ & $0.20 \pm 0.09^{a b}$ & $0.46 \pm 0.09^{a b}$ & $0.58 \pm 0.24^{\mathrm{bc}}$ \\
\hline $\mathrm{BC}_{7.5}+\mathrm{FA}$ & $161.67 \pm 21.96^{b}$ & $9.10 \pm 0.04$ & $0.09 \pm 0.00^{d}$ & $0.18 \pm 0.04^{\mathrm{ab}}$ & $0.19 \pm 0.08^{a b}$ & $0.54 \pm 0.09^{a}$ & $0.59 \pm 0.15^{\mathrm{bc}}$ \\
\hline $\mathrm{BC}_{30}+\mathrm{FA}$ & $143.33 \pm 19.60^{b}$ & $9.08 \pm 0.08$ & $0.21 \pm 0.06^{a}$ & $0.09 \pm 0.00^{d}$ & $0.30 \pm 0.18^{a}$ & $0.19 \pm 0.07^{c}$ & $0.27 \pm 0.07^{d}$ \\
\hline
\end{tabular}

${ }^{a}$ Different letters in a same row indicate significant differences $(p<0.05)$ between the treatments in a single year. EC, electrical conductivity; SAR, sodium adsorption ratio. $\mathrm{pH}$, soil reaction

Table 3: Influence of biochar, fulvic acid and nitrogen fertilizer on soil salinity (after barley)

\begin{tabular}{|c|c|c|c|c|c|c|c|c|}
\hline Treatment & $\begin{array}{c}\text { EC } \\
\left(\mu \mathrm{cm}^{-1}\right)\end{array}$ & $\mathrm{pH}$ & $\mathrm{K}^{+}\left(\mathbf{g ~ k g}^{-1}\right)$ & $\mathrm{Na}^{+}\left(\mathrm{g} \mathrm{kg}^{-1}\right)$ & $\begin{array}{c}\mathrm{Ca}^{2+}+\mathrm{Mg}^{2+} \\
\left(\mathrm{g} \mathrm{kg}^{-1}\right)\end{array}$ & $\begin{array}{c}\mathrm{HCO}_{3}{ }^{-}+\mathrm{CO}_{3}{ }^{2-} \\
\left(\mathrm{g} \mathrm{kg}^{-1}\right)\end{array}$ & $\mathrm{Cl}^{-}\left(\mathrm{g} \mathrm{kg}^{-1}\right)$ & $\begin{array}{c}\mathrm{SO}_{4}{ }^{2-} \\
\left(\mathrm{g} \mathrm{kg}^{-1}\right)\end{array}$ \\
\hline $\mathrm{N}$ & $141.90 \pm 0.10^{\mathrm{ab}}$ & $9.02 \pm 0.02^{\mathrm{a}}$ & $0.07 \pm 0.01^{\mathrm{b}}$ & $0.02 \pm 0.00^{c}$ & $0.12 \pm 0.01^{c}$ & $0.10 \pm 0.00^{\mathrm{a}}$ & $0.04 \pm 0.01^{b}$ & $0.01 \pm 0.00^{b}$ \\
\hline $\mathrm{BC}_{30}+\mathrm{N}$ & $127.33 \pm 9.03^{b}$ & $8.84 \pm 0.01^{b}$ & $0.13 \pm 0.01^{a}$ & $0.05 \pm 0.01^{b}$ & $0.18 \pm 0.09^{a b}$ & $0.08 \pm 0.01^{\mathrm{ab}}$ & $0.14 \pm 0.45^{a}$ & $0.06 \pm 0.01^{b}$ \\
\hline $\mathrm{FA}+\mathrm{N}$ & $125.83 \pm 15.28^{b}$ & $8.77 \pm 0.07^{c}$ & $0.09 \pm 0.01^{b}$ & $0.04 \pm 0.03^{c}$ & $0.17 \pm 0.08^{a}$ & $0.09 \pm 0.02^{a b}$ & $0.18 \pm 0.22^{a}$ & $0.03 \pm 0.06^{a}$ \\
\hline $\mathrm{BC}_{7.5}+\mathrm{FA}+\mathrm{N}$ & $126.20 \pm 3.16^{b}$ & $8.76 \pm 0.11^{c}$ & $0.10 \pm 0.01^{a}$ & $0.03 \pm 0.02^{c}$ & $0.27 \pm 0.07^{a}$ & $0.09 \pm 0.01^{\mathrm{ab}}$ & $0.08 \pm 0.05^{b}$ & $0.03 \pm 0.02^{\mathrm{a}}$ \\
\hline $\mathrm{BC}_{7.5}$ & $139.40 \pm 12.47^{\mathrm{ab}}$ & $8.90 \pm 0.03^{b}$ & $0.12 \pm 0.01^{a}$ & $0.08 \pm 0.01^{a}$ & $0.22 \pm 0.02^{\mathrm{a}}$ & $0.09 \pm 0.01^{\mathrm{ab}}$ & $0.05 \pm 0.02^{b}$ & $0.03 \pm 0.06^{\mathrm{ab}}$ \\
\hline $\mathrm{BC}_{30}$ & $142.03 \pm 16.98^{a b}$ & $8.99 \pm 0.66^{\mathrm{ab}}$ & $0.12 \pm 0.03^{a}$ & $0.09 \pm 0.05^{a}$ & $0.27 \pm 0.06^{a}$ & $0.08 \pm 0.02^{b}$ & $0.03 \pm 0.02^{b}$ & $0.02 \pm 0.01^{b}$ \\
\hline FA & $129.83 \pm 13.04^{\mathrm{ab}}$ & $8.78 \pm 0.03^{c}$ & $0.11 \pm 0.00^{a}$ & $0.06 \pm 0.01^{a b}$ & $0.18 \pm 0.03^{c}$ & $0.09 \pm 0.01^{\mathrm{ab}}$ & $0.06 \pm 0.02^{b}$ & $0.02 \pm 0.01^{b}$ \\
\hline $\mathrm{BC}_{7.5}+\mathrm{FA}$ & $147.37 \pm 12.00^{a}$ & $8.81 \pm 0.25^{b c}$ & $0.12 \pm 0.02^{a}$ & $0.06 \pm 0.04^{\mathrm{ab}}$ & $0.20 \pm 0.01^{c}$ & $0.10 \pm 0.01^{a}$ & $0.03 \pm 0.01^{b}$ & $0.02 \pm 0.00^{b}$ \\
\hline $\mathrm{BC}_{30}+\mathrm{FA}$ & $131.70 \pm 15.68^{a b}$ & $8.78 \pm 0.06^{c}$ & $0.12 \pm 0.01^{a}$ & $0.05 \pm 0.03^{a b}$ & $0.24 \pm 0.01^{a}$ & $0.09 \pm 0.01^{\mathrm{ab}}$ & $0.05 \pm 0.09^{b}$ & $0.02 \pm 0.01^{b}$ \\
\hline
\end{tabular}

Different letters in a same row indicate significant differences $(p<0.05)$ between the treatments in a single year. $\mathrm{EC}$, electrical conductivity; $\mathrm{pH}$, soil reaction.

\section{Soil physical properties}

Soil bulk density decreased with the addition of $\mathrm{BC}$ and/or FA while $\mathrm{N}$ considerably reduced its favorable effects after maize and barley crops (Table 4). The increase in the soil moisture content was $26.05 \%, 20.82 \%$ under $\mathrm{BC}_{30}$ and $\mathrm{BC}_{30}+\mathrm{FA}$ treatments over the control after the barley crop. However, no significant difference in soil moisture properties among all treatments was found after maize crop. The saturated water content of the soil was significantly improved, while the capillary porosity decreased with the addition of $\mathrm{BC}$ and/or FA. However, the increases in the soil water holding capacity varied with different $\mathrm{BC}$ dose. The values of saturated water content, field capacity, and total porosity remained maximum in the $\mathrm{BC}_{30}+\mathrm{FA}$ treatment, which was $40.80 \%, 27.41 \%$ and $53.97 \%$, respectively.

\section{Soil nutrient}

Soil total nitrogen content was higher in treatments without $\mathrm{N}$ addition than those with $\mathrm{N}$ application after maize and barley crop (Table 5). A considerable increase in the total nitrogen of soil was observed with the application of
$\mathrm{BC}_{30}+\mathrm{FA}$ after maize crop, and under $\mathrm{B}_{30}$ treatment after the barley crop, over the control. Total $\mathrm{P}$ in treatments after barley was lower than the same treatment after the maize crop. The total $P$ and available $P$ increased with the increased dose of BC. FA improved the promoting effects of $\mathrm{BC}$, and $\mathrm{BC}+\mathrm{FA}$ maintained more $\mathrm{N}$ and $\mathrm{P}$ than those treatments which contain $\mathrm{N}$ fertilizer. The total organic were increased by the application of $\mathrm{N}$ under $\mathrm{BC}$ and/or FA treatments. Nevertheless, no significant difference was found between $\mathrm{BC}$ and/or FA treatments and $\mathrm{BC}$ and/or FA $+\mathrm{N}$ treatments. The increase was $7.81,47.12,50.68,15.75,29.72,6.85,2.74$, 35.48, 6.71, 4.79 and $16.71 \%$ under $\mathrm{N}, \mathrm{BC}_{7.5}+\mathrm{N}, \mathrm{BC}_{30}+\mathrm{N}$, $\mathrm{FA}+\mathrm{N}, \mathrm{BC}_{7.5}+\mathrm{FA}+\mathrm{N}, \mathrm{BC}_{30}+\mathrm{FA}+\mathrm{N}, \mathrm{BC}_{7.5}, \mathrm{BC}_{30}, \mathrm{FA}$, $\mathrm{BC}_{7.5}+\mathrm{FA}, \mathrm{BC}_{30}+\mathrm{FA}$ treatment over the control after barley crop, respectively. Significantly increased TOC was observed in $\mathrm{C}_{7.5}+\mathrm{N}, \mathrm{BC}_{30}+\mathrm{N}$ and $\mathrm{BC}_{30}$ compared with control.

\section{Effect of BC, FA and $\mathrm{N}$ levels on yield and yield attributing characters}

Data of grain yield, thousand grain weight and straw height of maize observed at harvest period are shown in (Fig. 2,3). 


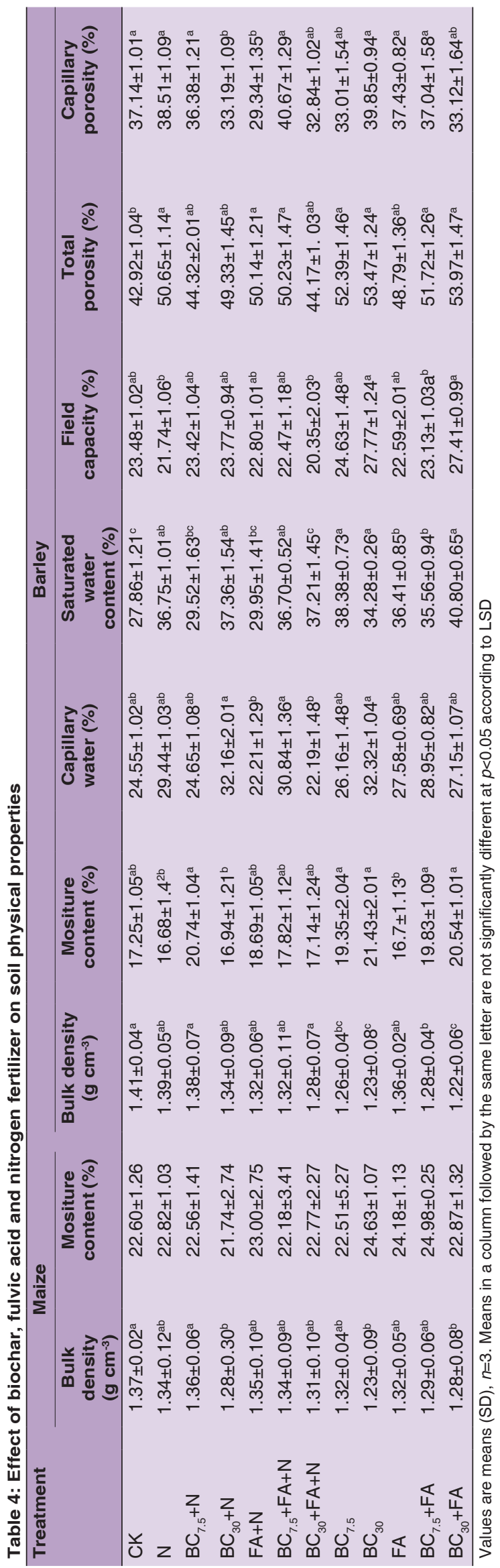

Remarkably, significant increases were observed in grain yield by $105 \%$ and $60 \%$, in thousand grain weight by $19 \%$ and $35 \%$, respectively, with $\mathrm{BC}_{30}+\mathrm{FA}+\mathrm{N}$ and $\mathrm{BC}_{7.5}+\mathrm{FA}+\mathrm{N}$ over the control. Meanwhile, there was a significant increase in maize height by $8.62 \%$ and $6.35 \%$, respectively, under $\mathrm{BC}_{7.5}+\mathrm{FA}+\mathrm{N}$ and $\mathrm{BC}_{30}+\mathrm{FA}+\mathrm{N}$ compared to $\mathrm{CK}$. Though $\mathrm{N}$ application improved grain yield of maize, no significant differences were found between $\mathrm{BC}$ and/or $\mathrm{FA}$ and $\mathrm{BC}$ and/or FA $+\mathrm{N}$ treatments (Fig. 2). Furthermore, thousand grain weight and plant height were all significantly decreased under treatments of $\mathrm{BC}_{7.5}$ and $\mathrm{BC}_{30}$ over the control (Fig. 3).

Grain and straw weights of barley are illustrated in (Fig. 4). $\mathrm{N}$ addition significantly increased the grain yield and straw weight of BC and/or FA treatments compared to no-N addition treatments. Grain yield was greatly increased in $\mathrm{BC}_{30}+\mathrm{FA}+\mathrm{N}$ and $\mathrm{BC}_{7.5}+\mathrm{FA}+\mathrm{N}$ treated plots, with by $350 \%$ and $325 \%$. However, the harvest indexes (HI) of the two treatments were lower than other treatments. Treatments with no $\mathrm{N}$ addition possessed a higher $\mathrm{HI}$ and lower crop yield. There was no significant increase between no- $\mathrm{N}$ treatments and CK.

\section{DISCUSSION}

\section{Effects of BC, FA, and $\mathrm{N}$ on soil salinity}

$\mathrm{BC}$ with highly porous structure and the large surface area is favorable for salt leaching and seed germination as well as root penetrating (Lashari et al., 2013). FA is a micromolecular complex comprised of aromatic hydroxy carboxylic acid. FA, as an essential constitute of organic matter, can be produced from different materials, and it is highly effective in improving soil conditions (Delgado et al., 2002; Yang et al., 2013). Of all the essential nutrients, nitrogen $(\mathrm{N})$ is required by plants in the largest quantity However, it is easily lost from the soil (Olfs et al., 2005). Coastal reclamation plays an important role in the mitigation of land-use pressure in the coastal zone brought by population growth and urbanization. The high salinity of soils was one of the most important environmental issues limiting the agriculture development in coastal areas (Yadav et al., 2011). The results here showed that amendment of $\mathrm{BC}, \mathrm{FA}$ and $\mathrm{N}$ caused a significant decrease in salt stress, and thus growth improvement of, the maize and barley crop. The values of $\mathrm{EC}$ and $\mathrm{pH}$ among all treatments showed no large difference, and such phenomenon might happen because of the great quantity of rain during the cultivation of maize and barley as shown in Fig. 1. The precipitation volume was more than double the mean precipitation content of the past 20 years during the experimental period in the present study. Rainwater accelerated the salt leaching, and the harmful soluble ions $\mathrm{Na}^{+}$and $\mathrm{Cl}^{-}$moved to deep soil layer with the gravity water (Zhang et al., 
Table 5: Soil nutrient contents at the end of each crop season

\begin{tabular}{|c|c|c|c|c|c|c|}
\hline \multirow[t]{2}{*}{ Treatment } & \multicolumn{3}{|c|}{ Maize } & \multicolumn{3}{|c|}{ Barley } \\
\hline & $\begin{array}{c}\mathrm{TN} \\
\left(\mathrm{mg} \mathrm{kg}^{-1}\right)\end{array}$ & $\begin{array}{c}\text { TP } \\
\left(\mathrm{mg} \mathrm{kg}^{-1}\right)\end{array}$ & $\begin{array}{c}\text { AP } \\
\left(\mathrm{mg} \mathrm{kg}^{-1}\right)\end{array}$ & $\begin{array}{c}\mathrm{TN} \\
\left(\mathrm{mg} \mathrm{kg}^{-1}\right)\end{array}$ & $\begin{array}{c}\mathrm{TP} \\
\left(\mathrm{mg} \mathrm{kg}^{-1}\right)\end{array}$ & $\begin{array}{c}\text { TOC } \\
\left(\mathrm{g} \mathrm{kg}^{-1}\right)\end{array}$ \\
\hline CK & $528.23 \pm 12.65^{c}$ & $216.59 \pm 12.55^{d}$ & $13.05 \pm 2.01^{b}$ & $411.63 \pm 17.04^{\mathrm{ab}}$ & $124.90 \pm 21.54^{\mathrm{ab}}$ & $7.30 \pm 0.17^{b}$ \\
\hline $\mathrm{N}$ & $598.26 \pm 14.19^{b c}$ & $240.45 \pm 23.15^{d}$ & $15.02 \pm 1.02^{\mathrm{ab}}$ & $633.90 \pm 36.04^{a}$ & $233.47 \pm 22.27^{\mathrm{ab}}$ & $7.87 \pm 0.09^{a b}$ \\
\hline $\mathrm{BC}_{7.5}+\mathrm{N}$ & $686.72 \pm 59.09^{a b}$ & $344.79 \pm 21.04^{c}$ & $15.31 \pm 2.18^{\mathrm{ab}}$ & $338.33 \pm 25.02^{\mathrm{ab}}$ & $198.10 \pm 12.09^{a b}$ & $10.74 \pm 0.18^{a}$ \\
\hline $\mathrm{BC}_{30}+\mathrm{N}$ & $879.81 \pm 73.39^{a b}$ & $559.78 \pm 25.02^{a}$ & $16.93 \pm 3.45^{\mathrm{a}}$ & $579.17 \pm 29.92^{a}$ & $168.52 \pm 22.71^{\mathrm{ab}}$ & $11.00 \pm 0.83^{\mathrm{a}}$ \\
\hline $\mathrm{FA}+\mathrm{N}$ & $853.77 \pm 62.59^{a b}$ & $306.35 \pm 51.66^{c}$ & $16.02 \pm 2.02^{a}$ & $339.17 \pm 37.24^{\mathrm{ab}}$ & $251.79 \pm 65.31^{\mathrm{ab}}$ & $8.45 \pm 1.26^{\mathrm{ab}}$ \\
\hline $\mathrm{BC}_{7.5}+\mathrm{FA}+\mathrm{N}$ & $632.34 \pm 20.68^{a b}$ & $250.13 \pm 22.01^{c d}$ & $17.14 \pm 2.85^{\mathrm{a}}$ & $292.50 \pm 30.41^{b}$ & $215.62 \pm 69.51^{\mathrm{ab}}$ & $9.47 \pm 0.97^{a}$ \\
\hline $\mathrm{BC}_{30}+\mathrm{FA}+\mathrm{N}$ & $951.79 \pm 76.43^{a b}$ & $503.84 \pm 76.87^{a}$ & $17.14 \pm 1.63^{a}$ & $354.17 \pm 22.68^{\mathrm{ab}}$ & $204.73 \pm 27.24^{\mathrm{ab}}$ & $7.80 \pm 0.02^{\mathrm{ab}}$ \\
\hline $\mathrm{BC}_{7.5}$ & $829.12 \pm 39.32^{\mathrm{ab}}$ & $419.46 \pm 83.74^{b}$ & $17.46 \pm 1.60^{a}$ & $269.17 \pm 25.98^{b}$ & $189.69 \pm 78.96^{\mathrm{ab}}$ & $7.50 \pm 0.54^{b}$ \\
\hline $\mathrm{BC}_{30}$ & $1027.31 \pm 60.35^{a}$ & $488.69 \pm 55.13^{a b}$ & $17.43 \pm 0.79^{a}$ & $992.50 \pm 31.88^{a}$ & $305.91 \pm 20.92^{a}$ & $9.89 \pm 0.77^{\mathrm{ab}}$ \\
\hline FA & $1264.82 \pm 76.17^{a}$ & $402.62 \pm 79.49^{b c}$ & $15.88 \pm 3.40^{\mathrm{ab}}$ & $470.00 \pm 57.86^{a}$ & $145.68 \pm 46.09^{b}$ & $7.79 \pm 0.45^{\mathrm{ab}}$ \\
\hline $\mathrm{BC}_{7.5}+\mathrm{FA}$ & $1384.03 \pm 71.75^{a}$ & $484.38 \pm 58.97^{b}$ & $18.96 \pm 2.65^{a}$ & $497.50 \pm 79.80^{a}$ & $108.69 \pm 3.52^{b}$ & $7.65 \pm 0.89^{a b}$ \\
\hline $\mathrm{BC}_{30}+\mathrm{FA}$ & $1796.49 \pm 69.56^{a}$ & $543.19 \pm 37.58^{a}$ & $19.54 \pm 1.02^{\mathrm{a}}$ & $462.51 \pm 12.68^{a}$ & $223.92 \pm 56.41^{\mathrm{ab}}$ & $8.52 \pm 0.64^{b}$ \\
\hline
\end{tabular}

aValues are means (SD), $n=3$. Means in a column followed by the same letter are not significantly different at $p<0.05$ according to LSD. TN, total nitrogen; TP, total phosphorus; AP, available phosphorus; TOC, total organic carbon

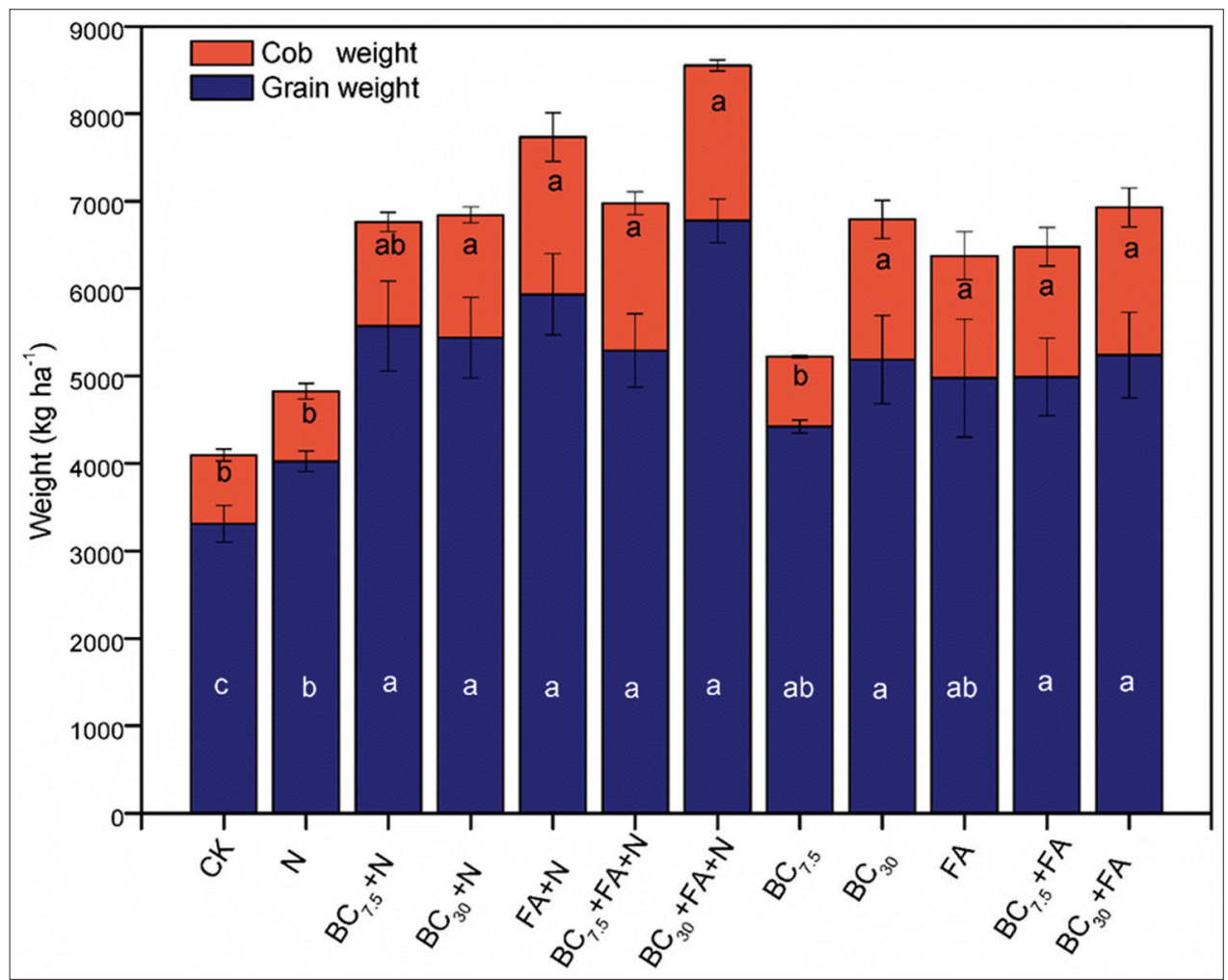

Fig 2. Grain weight, cob weight of maize under the different treatments. Values are means \pm SD $(n=3)$. Bars within each panel with different letters are significantly different according to LSD at $(p<0.05)$.

2014a). Meanwhile, the $\mathrm{pH}$ value was above 9.0 after maize in all the treatments, and the value was larger as compared with initial $\mathrm{pH}$ of the soil. Furthermore, the $\mathrm{pH}$ was above 8.5 after barley in each treatment, which indicated the soil alkalinity. The potassium $\left(\mathrm{K}^{+}\right)$content was less than sodium $\left(\mathrm{Na}^{+}\right)$content in all treatments after maize, and the situation was opposite after barley crop. Although $\mathrm{K}^{+}$is chemically similar to $\mathrm{Na}^{+}, \mathrm{K}^{+}$is an essential plant nutrient and plays an important role in a number of biochemical and physiological processes that link to resistance to abiotic stresses such as soil salinity (Yaldiz et al., 2018). The high soil $\mathrm{pH}$ was attributed to an accumulation of potassium or sodium in soil as $\mathrm{K}$ and/or $\mathrm{Na}$ accumulation in soil enhances formation of potassium bicarbonate $\left(\mathrm{KHCO}_{3}\right)$, sodium bicarbonate $\left(\mathrm{NaCO}_{3}\right)$, potassium carbonate $\left(\mathrm{K}_{2} \mathrm{CO}_{3}\right)$ and sodium carbonate $\left(\mathrm{NaCO}_{3}\right)$ and consequently increased soil $\mathrm{pH}$ (Adams et al., 1982; Rengasamy et al., 2003; Rogovska 


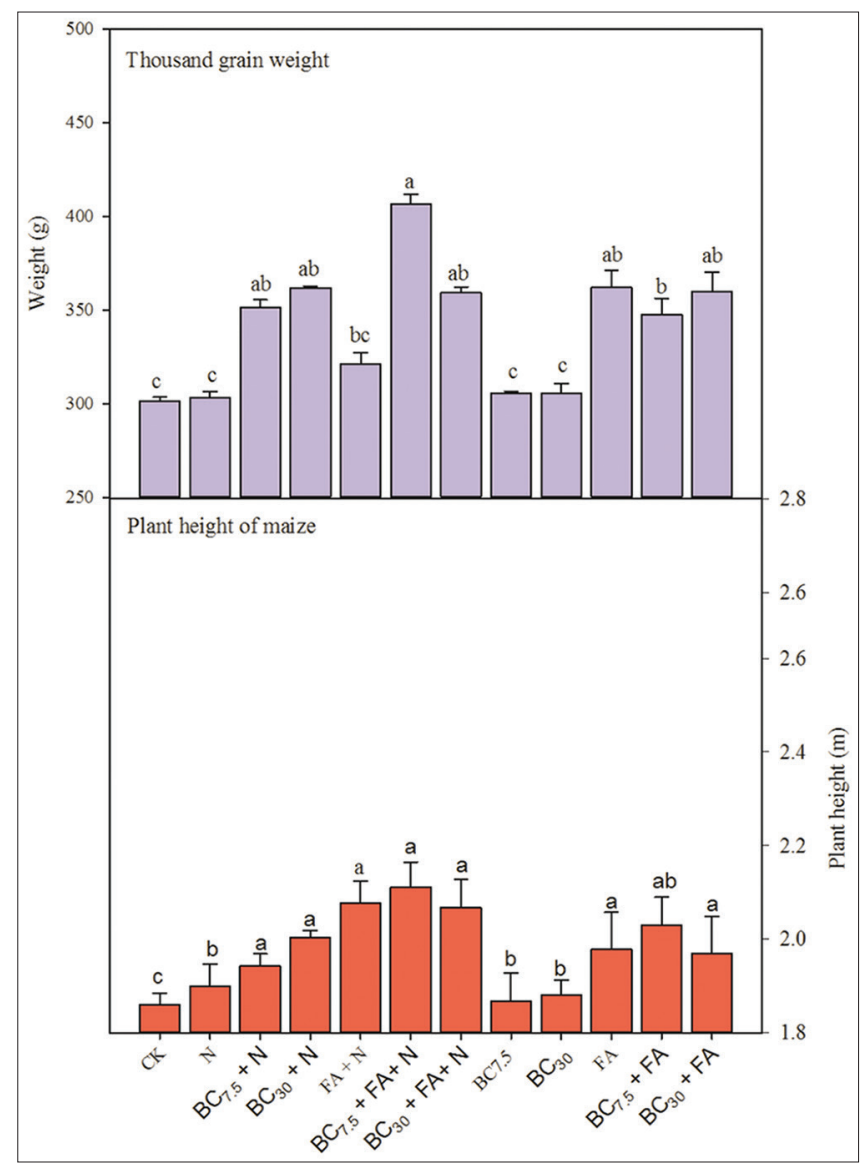

Fig 3. Thousand grain weight and plant height of maize as affected by biochar (BC), fulvic acid (FA) and nitrogen fertilizer (N).Values are means $\pm \mathrm{SD}(n=3)$. For each parameter, bars within each panel with different letters are significantly different according to LSD at $(p<0.05)$. et al., 2007). Besides, BC added appreciable amounts of additional $\mathrm{Ca}^{2+}$ and $\mathrm{Mg}^{2+}$ to soil (Table 1). Therefore, replacement of $\mathrm{K}^{+}$and $\mathrm{Na}^{+}$by $\mathrm{Ca}^{2+}$ in the soil colloid led to an increase in soluble $\mathrm{K}^{+}$and $\mathrm{Na}^{+}$, and then the soluble ions were washed through the rainfall (Mahmoodabadi et al., 2013).

\section{Effects of $B C, F A$, and $\mathbf{N}$ on soil physical properties}

The BD values in all plots except the control and $\mathrm{N}$ treatments decreased after maize and barley crops. In good agreement with (Zhang et al., 2014b), BC and humic acid (contains FA) application decreased soil BD and increased the soil water holding capacity. However, the extreme precipitation (da Silva et al., 2003) and N application (Batey, 2009) caused the soil compaction during the maize cultivation. In addition, the $\mathrm{BD}$ values at depth of $0-20 \mathrm{~cm}$ in $\mathrm{BC}$ and/or FA with $\mathrm{N}$ treatments were lower than that in no- $\mathrm{N}$ application treatments. The soil water contents were lower in $\mathrm{N}$ addition plots after maize and barley crop. The BC + FA treatments showed a better effect on water retention and soil porosity than $\mathrm{BC}$ or FA. Combined addition of $\mathrm{BC}$ and $\mathrm{FA}$ shifted values for water holding capacity, total porosity, available porosity, and field capacity into the optimal ranges and increased porosity and water retention. Similar results were reported by (Obia et al., 2016; Suliman et al., 2017) which described that BC or FA improved the particle structure of the soil.

Otherwise, soil bulk density increased with soil depth, which may be attributed to the higher organic matter content in

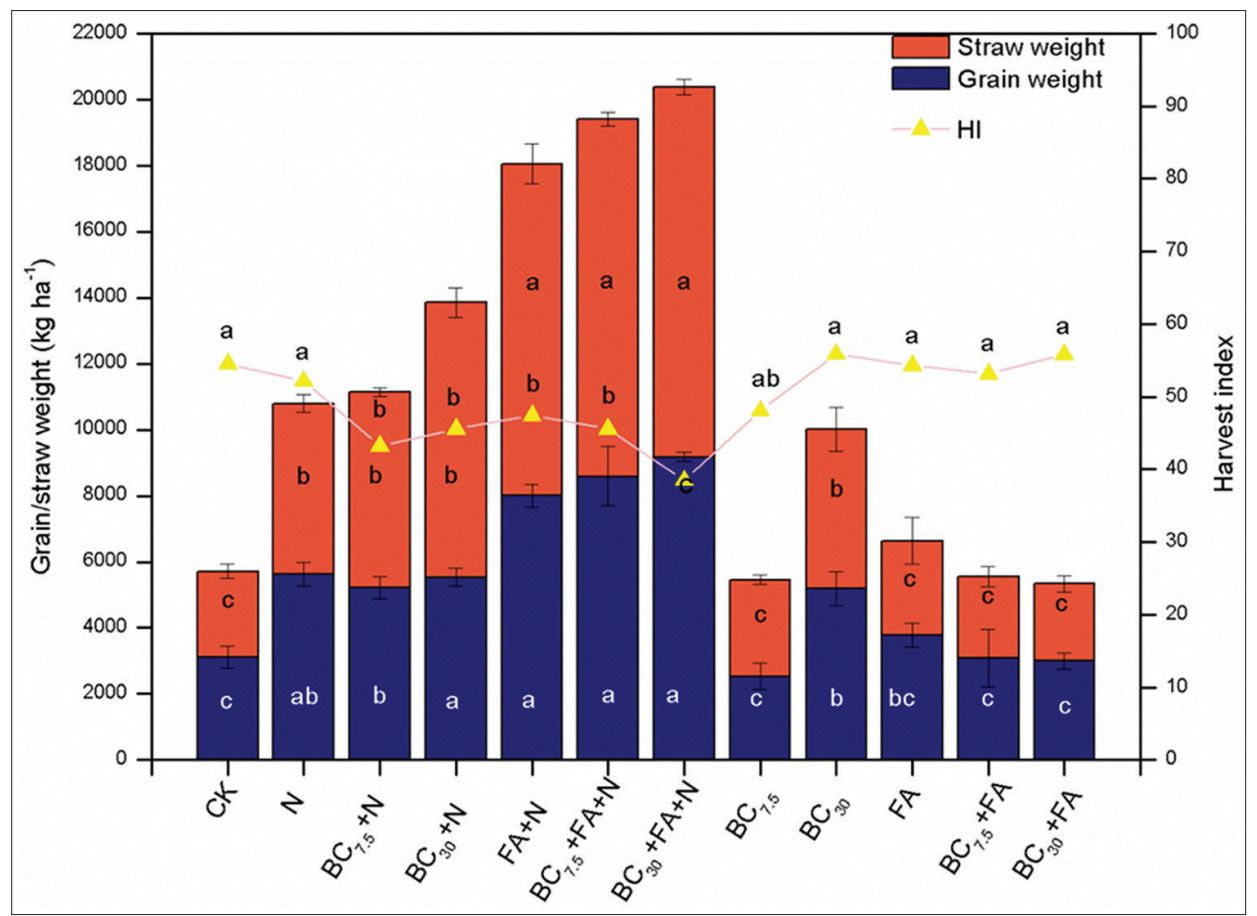

Fig 4. Grain and straw yields and harvest index $(\mathrm{HI})$ after barley cultivation under different treatments. Error bars represent one standard deviation of the mean. Different letters in the same row indicate significant differences $(p<0.05)$ between the treatments. HI, the ratio of grain weight to straw weight. 
the surface layer and the tillage practices (Manrique and Jones, 1991). Furthermore, BD is required to evaluate, estimate, and calculate many physical soil properties such as soil porosity, heat capacity, water retention, and compressibility (Ruehlmann and Korschens, 2009).

\section{Effects of BC, FA, and $\mathrm{N}$ on soil nutrient supply and yield}

Soil sediments from reclamation are rich in nitrogen and phosphorus (Table 1). Nitrogen is a very dynamic element, and it also lose from the soil through volatilization, run-off and leaching. The soil nitrogen lost easily, as the extreme precipitation and high temperature existed during the experimental period (Fig. 4). Nevertheless, phosphorus is low availability due to slow diffusion and high fixation in soils (Shen et al., 2011). Though the soil salt decreased during the crop cultivation, the soil reaction was higher than 8.5. A major problem in alkaline soils is the reduced nutrient, and especially micronutrient, availability. $\mathrm{N}$ addition slightly improved the grain yield of maize, and $\mathrm{BC}$ and/or FA application produced a higher yield than $\mathrm{N}$ treatment. Besides, the soil nutrient content is higher, under treatments without $\mathrm{N}$ compared to $\mathrm{N}$ added plots. $\mathrm{BC}_{30}+\mathrm{FA}$ was the optimal treatment for improving soil nutrient-holding capacity. The higher grain yields indicated that nutrients uptake were more efficient under $\mathrm{N}$ application treatments, over no-N treatments. Similar results were obtained by (Long et al., 2008; Zhang et al., 2012). BC and/or FA treatments produced no more benefits than the control during barley cultivation. This may be caused by the lower microbial activity for the high $\mathrm{pH}$ and the lack of available organic carbon. Otherwise, the low microbial activity inhibits the nitrogen and phosphorus mineralization (Franzluebbers et al., 1995; Zhang et al., 2017).

\section{CONCLUSION}

The current study demonstrated that $\mathrm{BC}+\mathrm{FA}$ was a potentially suitable candidate amendment and fertilizer for producing food and soil improvement in the newly reclaimed tidal land. This treatment improved both the physicochemical and nutritional properties of the soil and increased crop yield. $\mathrm{N}$ application and extreme precipitation caused soil compaction, while BC and/or FA addition alleviated soil physical stress. The beneficial effects of $\mathrm{BC}$ and/or FA without $\mathrm{N}$ addition on crop yield only continued throughout a single growing season. However, its benefits on soil nutrition storage, porosity and water retention were sustained after the barley crop. The effects was especially significant under the $\mathrm{BC}_{30}+\mathrm{FA}$ treatment. Otherwise, no-N addition is obviously helpful to protect the coastal environment. Further investigation will focus on the microbial mechanism of $\mathrm{N}$ mineralization in the saline soil with BC and FA application. At the same time, more useful measures should be taken to maintain a winwin situation in agriculture and coastal ecosystem.

\section{ACKNOWLEDGEMENTS}

This work was supported by the National Key Research and Development Program of China under Grant 2016YFD0200303 and 2016YFC0501309; the National Sci-Tech Support Plan under Grant 2015BAD01B03; and the Key R\&D Project (Modern Agriculture) of Jiangsu Province under Grant BE2015337.

\section{Author contributions}

Y.S., J.Y., R.Y. and X.C. conceived and designed the research; Y.S. and R.Y. performed the research; Y.S., J.Y. and X.C. wrote the paper and approved the final version to be published.

\section{REFERENCES}

Abbas, TahirT., Muhammad M. Rizwan, Shafaqat S. Ali, Muhammad M. Adrees, Muhammad M. Zia-ur-Rehman, Muhammad M. Farooq F. Qayyum, Yong Y. Sik S. Ok and Ghulam G. Murtaza. 2017. Effect of biochar on alleviation of cadmium toxicity in wheat (Triticum aestivum L.) grown on Cd-contaminated saline soil. Environ. Sci. Pollut. R. 26:25668-25680.

Abiven, S., M. W. I. Schmidt and J. Lehmann. 2014. Biochar by design. Nat. Geosci. 7:326-327.

Adams, J. F., F. Adams and J. W. Odom. 1982. Interaction of phosphorus rates and soil-ph on soybean yield and soil solution composition of 2 phosphorus-sufficient ultisols. Soil Sci. Soc. Am. J. 46:323-328.

Almaroai, Y. A., A. R. A. Usman, M. Ahmad, D. H. Moon, J. S. Cho, Y. K. Joo, C. Jeon, S. S. Lee and Y. Ok. 2014. Effects of biochar, cow bone, and eggshell on $\mathrm{Pb}$ availability to maize in contaminated soil irrigated with saline water. Environ. Earth Sci. 71:1289-1296.

Batey, T. 2009. Soil compaction and soil management a review. Soil Use Manage. 25:335-345.

Chen, L. J., C. S. Li, Q. Feng, Y. P. Wei, H. Zheng, Y. Zhao, Y. J. Feng and H. Y. Li. 2017. Shifts in soil microbial metabolic activities and community structures along a salinity gradient of irrigation water in a typical arid region of China. Sci. Total Environ. 598:64-70.

da Silva, A. P., S. Imhoff and M. Corsi. 2003. Evaluation of soil compaction in an irrigated short-duration grazing system. Soil Till. Res. 70:83-90.

Deinlein, U., A. B. Stephan, T. Horie, W. Luo, G. H. Xu and J. I. Schroeder. 2014. Plant salt-tolerance mechanisms. Trends Plant Sci. 19:371-379.

Delgado, A., A. Madrid, S. Kassem, L. Andreu and M. D. del Campillo. 2002. Phosphorus fertilizer recovery from calcareous soils amended with humic and fulvic acids. Plant Soil. 245: 277-286.

Dinler, B. S., E. Gunduzer and T. Tekinay. 2016. Pre-treatment of fulvic acid plays a stimulant role in protection of soybean (Glycine max L.) leaves against heat and salt stress. Acta Biol. Cracov. Bot. 58: 29-41. 
Drake, J. A., T. R. Cavagnaro, S. C. Cunningham, W. R. Jackson and A. F. Patti. 2016. Does biochar improve establishment of tree seedlings in saline sodic soils? Land Degrad. Dev. 27: 52-59.

Fang, J., K. K. Zhang, P. D. Sun, D. H. Lin, B. Shen and Y. Luo. 2016. Co-transport of $\mathrm{Pb} 2+$ and $\mathrm{TiO} 2$ nanoparticles in repacked homogeneous soil columns under saturation condition: Effect of ionic strength and fulvic acid. Sci. Total Environ. 571: 471-478.

Franzluebbers, A. J., F. M. Hons and D. A. Zuberer. 1995. Soil Organic-carbon, microbial biomass, and mineralizable carbon and nitrogen in sorghum. Soil Sci. Soc. Am. J. 59: 460-466.

He, Q., M. D. Bertness, J. F. Bruno, B. Li, G. Chen, T. C. Coverdale, A. H. Altieri, J. Bai, T. Sun, S. C. Pennings, J. Liu, P. R. Ehrlich and B. Cui. 2014. Economic development and coastal ecosystem change in China. Sci. Sci. Rep. 4: 5995.

Kim, H. S., K. R. Kim, J. E. Yang, Y. S. Ok, G. Owens, T. Nehls, G. Wessolek and K. H. Kim. 2016. Effect of biochar on reclaimed tidal land soil properties and maize (Zea mays L.) response. Chemosphere. 142: 153-159.

Lashari, M. S., Y. M. Liu, L. Q. Li, W. N. Pan, J. Y. Fu, G. X. Pan, J. F. Zheng, J. W. Zheng, X. H. Zhang and X. Y. Yu. 2013. Effects of amendment of biochar-manure compost in conjunction with pyroligneous solution on soil quality and wheat yield of a saltstressed cropland from central China great plain. Field Crop. Res. 144: 113-118.

Lehmann, J. 2007. A handful of carbon. Nature. 447: 143-144.

Lehmann, J., M. C. Rillig, J. Thies, C. A. Masiello, W. C. Hockaday and D. Crowley. 2011. Biochar effects on soil biota a review. Soil Biol. Biochem. 43: 1812-1836.

Li, Y., W. F. Tan, L. K. Koopal, M. X. Wang, F. Liu and W. Norde. 2013. Influence of soil humic and fulvic acid on the activity and stability of lysozyme and urease. Environ. Sci. Technol. 47: 5050-5056.

Liu, D., J. K. Keesing, P. He, Z. Wang, Y. Shi and Y. Wang. 2013. The world's largest macroalgal bloom in the yellow sea, China: Formation and implications. Estuar. Coast. Shelf Sci. 129: 2-10.

Liu, F., S. J. Pang, T. Chopin, S. Q. Gao, T. F. Shan, X. B. Zhao and J. Li. 2013. Understanding the recurrent large-scale green tide in the yellow sea: Temporal and spatial correlations between multiple geographical, aquacultural and biological factors. Mar. Environ. Res. 83: 38-47.

Long, X. H., S. K. Mehta and Z. P. Liu. 2008. Effect of NO3-N enrichment on seawater stress tolerance of jerusalem artichoke (Helianthus tuberosus). Pedosphere. 18: 113-123.

Luo, X. X., G. C. Liu, Y. Xia, L. Chen, Z. X. Jiang, H. Zheng and Z. Y. Wang. 2017. Use of biochar-compost to improve properties and productivity of the degraded coastal soil in the yellow river delta, China. J. Soil Sediment. 17: 780-789.

Mahmoodabadi, M., N. Yazdanpanah, L. R. Sinobas, E. Pazira and A. Neshat. 2013. Reclamation of calcareous saline sodic soil with different amendments(I): Redistribution of soluble cations within the soil profile. Agric. Water Manage. 120: 30-38.

Manrique, L. A. and C. A. Jones. 1991. Bulk-density of soils in relation to soil physical and chemical-properties. Soil Sci. Soc. Am. J. 55: 476-481.

Min, W., H. J. Guo, G. W. Zhou, W. Zhang, L. J. Ma, J. Ye, Z. N. Hou and L. S. Wu. 2016. Soil salinity, leaching, and cotton growth as affected by saline water drip irrigation and $\mathrm{N}$ fertigation. Acta Agric. Scand. 66: 489-501.

Nan, J. K., X. M. Chen, C. Chen, M. S. Lashari, J. Q. Deng, Z. J. Du. 2016. Impact of flue gas desulfurizaiton gypsum and lignite humic acid application on soil orgainc matter and physical properties of saline-sodic farmland soil in Eastern China. J. Soil. Sediment. 9: 2175-2185.
Obia, A., J. Mulder, V. Martinsen, G. Cornelissen and T. Borresen. 2016. In situ effects of biochar on aggregation, water retention and porosity in light-textured tropical soils. Soil Till. Res. 155: 35-44.

Olfs, H. W., K. Blankenau, F. Brentrup, J. Jasper, A. Link and J. Lammel. 2005. Soil- and plant-based nitrogen-fertilizer recommendations in arable farming. J. Plant Nutr. Soil Sc. 168: 414-420.

Rawat, L., Y. Singh, N. Shukla and J. Kumar. 2011. Alleviation of the adverse effects of salinity stress in wheat (Triticum aestivum L.) by seed biopriming with salinity tolerant isolates of Trichoderma harzianum. Plant Soil. 347: 387-400.

Rengasamy, P., D. Chittleborough and K. Helyar. 2003. Root-zone constraints and plant-based solutions for dryland salinity. Plant Soil. 257: 249-260.

Rogovska, N. P., A. M. Blackmer, A. P. Mallarino. 2007. Relationships between soybean yield, soil $\mathrm{pH}$, and soil carbonate concentration. Soil Sci. Am. J. 71: 1251-1256.

Ruehlmann, J. and M. Korschens. 2009. Calculating the effect of soil organic matter concentration on soil bulk density. Soil Sci. Soc. Am. J. 73: 876-885.

Shen, J. B., L. X. Yuan, J. L. Zhang, H. G. Li, Z. H. Bai, X. P. Chen, W. F. Zhang and F. S. Zhang. 2011. Phosphorus dynamics: From soil to plant. Plant Physiol. 156: 997-1005.

Sousa, A. F., O. B. Weber, L. A. Crisostomo, M. E. O. Escobar and T. S. de Oliveira. 2017. Changes in soil soluble salts and plant growth in a sandy soil irrigated with treated water from oil extraction. Agric. Water Manage. 193: 13-21.

Suliman, W., J. B. Harsh, N. I. Abu-Lail, A. M. Fortuna, I. Dallmeyer and M. Garcia-Perez. 2017. The role of biochar porosity and surface functionality in augmenting hydrologic properties of a sandy soil. Sci. Total Environ. 574: 139-147.

Sun, H. J., H. Y. Lu, L. Chu, H. B. Shao and W. M. Shi. 2017. Biochar applied with appropriate rates can reduce $\mathrm{N}$ leaching, keep $\mathrm{N}$ retention and not increase $\mathrm{NH} 3$ volatilization in a coastal saline soil. Sci. Total Environ. 575: 820-825.

Sun, Y. G., X. Z. Li, U. Mander, Y. L. He, Y. Jia, Z. G. Ma, W. Y. Guo and Z. J. Xin. 2011. Effect of reclamation time and land use on soil properties in changjiang river estuary, China. Chinese Chin. Geogr. Sci. 21: 403-416.

Visconti, F., J. M. De Paz and J. L. Rubio. 2010. Calcite and gypsum solubility products in water-saturated salt-affected soil samples at 25 degrees $\mathrm{C}$ and at least up to $14 \mathrm{dS} \mathrm{m}(-1)$. Eur. J. Soil Sci. 61: $255-270$.

Wang, E. H. 2017. Nitrogen Pollution in the Surface Sediments and Communities of Bacteriophankton Response to Nitrogen Among Different Intertidal Zones. Yantai Institute of Coastal Zone Research, Yantai.

Yadav, S., M. Irfan, A. Ahmad and S. Hayat. 2011. Causes of salinity and plant manifestations to salt stress: A review. J. Environ. Biol. 32: 667-685.

Yaldiz, G., F. Ozen, M. Camlica and F. Sonmez. 2018. Alleviation of salt stress by increasing potassium sulphate doses in four medicinal and aromatic plants. Acta Agr. Scand. B.-S. P. 68: 437-447.

Yang, S. J., L. Cong, X. F. Wang, Z. F. Zhang and Z. L. Zhang. 2014. Fulvic acid displaces manure to improve soil in vegetable greenhouse. Acta Agr. Scand. 64: 454-461.

Yang, S., Z. Zhang, L. Cong, X. Wang and S. Shi. 2013. Effect of fulvic acid on the phosphorus availability in acid soil. J. Soil Sci. Plant Nut. 13: 526-533.

Yin, A. J., C. Gao, M. Zhang, P. B. Wu and X. H. Yang. 2017. Rapid changes in phosphorus species in soils developed on reclaimed tidal flat sediments. Geoderma. 307: 46-53. 
Yu, J. B., Z. C. Wang, F. X. Meixner, F. Yang, H. F. Wu and X. B. Chen. 2010. Biogeochemical Characterizations and Reclamation Strategies of saline sodic soil in Northeastern China. Clean Soil Air Water. 38: 1010-1016.

Yu, S., B. Cui, C. Xie, X. Ma, Y. Man and Z. Ning. 2019. Ecological offsetting in China's coastal wetlands: Existing challenges and strategies for future improvement. Chinese Chin. Geogr. Sci. 29: 202-213.

Zhang, C. M., L. Li and D. Lockington. 2014. Numerical study of evaporation-induced salt accumulation and precipitation in bare saline soils: Mechanism and feedback. Water Resour. Res. 50: 8084-8106.
Zhang, D. M., W. J. Li, C. S. Xin, W. Tang, A. E. Eneji and H. Z. Dong 2012. Lint yield and nitrogen use efficiency of field-grown cotton vary with soil salinity and nitrogen application rate. Field Crop. Res. 138: 63-70.

Zhang, L., X. Y. Sun, Y. Tian and X. Q. Gong. 2014. Biochar and humic acid amendments improve the quality of composted green waste as a growth medium for the ornamental plant Calathea insignis. Sci. Hortic. 176: 70-78.

Zhang, Y. T., H. Shen, X. H. He, B. Thomas, N. Z. Lupwayi, X. Y. Hao, M. C. Thomas and X. J. Shi. 2017. Fertilization shapes bacterial community structure by alteration of soil $\mathrm{pH}$. Front. Microbiol. 8:1325-1332. 